\title{
What Does It Mean to Be an EU Citizen? How News Media Construct Civic and Cultural Concepts of Europe
}

\author{
Sanna Inthorn \\ University of East Anglia
}

Keywords: $\quad$ European Identity, EU Enlargement, News

\begin{abstract}
The official accession criteria for EU membership define the Union as a civic community. Yet, in the debate over enlargement the definition of 'Europeanness' remains complex and EU membership at times becomes a question of cultural affinity. Arguing that the media play a key role in shaping European identities, this study explores how British and German press coverage since 2001 ascribes both civic and cultural components to EU membership. Its analysis of the representation of Turkey and Central and Eastern European countries reveals a complex and context-dependant concept of European identity. While overall we can see a civic and culturally inclusive concept, when it comes to Turkey cultural criteria appear as well. Whereas Central and Eastern European countries are presented as 'natural' members of the European family, Turkey remains its 'other' and is excluded on the basis of its cultural identity.
\end{abstract}

\section{Introduction}

The question of a common identity has become one of the central challenges facing the European Union (hereafter EU) today. While on policy level we see an accelerated drive towards further integration, at the same time there is a lack of popular support for this process. Concerns over a lack of common European political identity, or 'will' have been raised (Mayer and Palmowski 2004, 574). European citizens articulate a rough idea of what the EU represents, how it works, and what its costs and benefits to its members are (Bruter 2003, 36). They describe Europe as being about 'peace, harmony, the fading of historical divisions and cooperation between similar peoples and cultures'. 'Borderlessness, circulation of citizens, common civic area, new policy making and prosperity' are imagined to be elements of European identity (Ibid). Yet while there is a sense of what 'Europe' might be and what the EU stands for, there is no clear evidence to suggest that the citizens of Europe have adopted a European identity themselves to the extent that

Westminster Papers in Communication and Culture (C) 2006 (University of Westminster, London), Vol. 3(3): 71-90. ISSN 1744-6708 (Print); 1744-6716 (Online) 
it becomes the main framework through which they interpret European integration. In everyday narratives perceptions of Europe remain largely anchored in local and national contexts (Armbruster et al. 2003; Medrano 2003). A clear sense of belonging to Europe only appears to develop when European identity is challenged and in the process of being redefined. Citizens imagine themselves as members of a European community of values when faced with the prospect of further EU enlargement (see Armbruster et al. 2003). They express their European identity by distinguishing themselves from potential newcomers, such as the Balkans who are deemed 'un-European' (Ibid, 896). Yet overall, citizens appear to show little interest in European issues and rarely identify with a concept of European identity. Even in countries of traditionally high public support for European integration, such as Germany, public enthusiasm has been waning for some time (Busch and Knelangen 2004). Low levels of citizen engagement show in low voter turnout for European Parliament elections (EurActiv.Com 2004). They also reveal themselves in citizens' lack of interest in European issues. Even though most members of the public see their daily lives influenced by the EU initiatives, they do not necessarily take a keen interest in European integration. Information offered by news reports about the EU tends to be registered for a while, but is then forgotten (Medrano 2003, 22).

Political apathy and a lack of common identity among EU citizens have raised concerns over the extent to which the public are adequately informed about the process of European integration. As most people derive information about the EU from the media (Medrano 2003, 22), news coverage of European integration has come under scrutiny. Several studies to date have documented Euroscepticism in media discourse. They identified omissions and distortions of EU issues in news reporting (Hardt-Mautner 1995; Anderson and Weymouth 1999; Anderson 2004). There is evidence to suggest that such, often negative, media messages may influence readers' attitudes towards Europe, in particular when they correspond with attitudes that are perpetuated by political parties (Carey and Burton 2004). Thus, when we want to know why the people of Europe seem to lack a common political 'will', a look at media representations of European issues gives us an insight into what some of this citizen 'apathy' is based on. The present study neither wishes to make claims about direct media effects, nor is it able to indicate the exact extent to which media messages influence citizens' perceptions of Europe. Yet it wishes to acknowledge the role of the media as widely distributed agents in the imagining of collective identities. For most citizens news media are the main source of information about politics and politicians (Hargreaves and Thomas 2002). They shape our understanding of the world and our place within it. Thus, this study argues that news media contribute to our understanding of what it means to belong to a cultural and political collectivity, such as Europe. The question of what it means to belong to Europe is of continued importance in the context of European enlargement. This particular aspect of European integration 
challenges citizens and politicians alike to define their concept of what it means to be a European. While the official accession criteria define the EU as a civic community, in the debate over enlargement 'unofficial' cultural criteria, such as Christian heritage, crop up. Based on an analysis of British and German press coverage since 2001, this study suggests that media discourse teaches us that being a European citizen means sharing not just civic, but also cultural values. Comparing the representation of Turkey with the representation of Central and Eastern European Countries (hereafter CEECs), it shows that while CEECs are imagined as 'natural' members of the European family, Turkey is excluded on the basis of its cultural identity.

\section{Civic and Cultural Elements of European Identity}

The official membership criteria, agreed at the 1993 Copenhagen summit, require that candidate countries must have achieved stability of institutions, guaranteeing democracy, the rule of law, human rights as well as respect for and protection of minorities. Candidate states have to show the existence of a functioning market economy and the ability to take on the obligations of membership including the aims of political, economic and monetary union. Following the 1995 European Council in Madrid, candidates are also required to create the conditions for integration through the adjustment of administrative structures (European Commission Directorate-General $\mathrm{n} / \mathrm{d}$ ). Notably, these are all criteria that are closely tied to a civic concept of identity: They define citizens' ties with the democratic institutions of their state. The concept of European identity as it is expressed by these criteria thus remains largely civic in nature. Cultural criteria, such as religion, are not part of its constitutive elements. However, while in EU texts care is taken to avoid a definition of European identity on mainly cultural terms, in the history of European enlargement, the concept of 'European culture' crops up nevertheless (Delgado-Moreira 1997). In 1998 accession negotiations started with Cyprus, Hungary, Poland, Estonia, the Czech Republic and Slovenia. In 1999 the European Council in Helsinki decided to also start negotiations with Bulgaria, Romania, Latvia, Lithuania, Malta, and Slovakia (Infoeuropa, n/d). As Sjursen (2001) points out, the raison d'etre behind this process was not altogether clear from the start as the EU-wide advantages of enlargement are not certain. There is the possibility that large-scale enlargement might threaten the internal order of the EU. New divisions across the European continent could develop as new borders are drawn and resentment against the EU might rise in applicant countries due to the economic and institutional adaptations required from them. Moreover, the economic costs of enlargement are likely to outweigh the gains in the short and medium term. Further, new members bring different foreign policy perspectives, as well as new neighbours, into the EU, making future decisionmaking more difficult. Thus, as the process of enlargement was set into motion, the gains it would bring seemed limited. A utility argument does not hold as 
explanation for the EU 'yes' to enlargement (Ibid). Nevertheless enlargement in principle was accepted by all EU members. There have been signs of reluctance against Eastern enlargement. Delays in trade liberalisation and the restriction of CEECs' exports into the EU signal this. However, while delay reflects reluctance to enlarge due to the economic costs it might bring, economic reasoning has not been used to refuse enlargement (Ibid). In the case of CEECs a sense of common values, shared by the 'community of Europeans', appears to have been a strong deciding factor behind the EU's decision to enlarge. In EU statements Eastern and Western Europe appeared imagined as two parts of the same entity. CEECs figured as the 'kidnapped West', now freed from the clutches of the Russian empire. The EU became defined as a community of norms and values from which CEECs had been excluded (Jileva 2004, 9). The EU seemingly had a 'moral duty' to assist these 'natural' members of the European family in their recovery from a totalitarian past and economic hardship. Since the process of accession was set into motion, political rhetoric in Eastern European countries, as well as in Western Europe, have utilised this concept of the formerly 'lost' East which now should take its rightful place in the seat of the European family. With CEECs countries placed back into the imagined community of European values, Russia has becomes the 'other' in the dichotomy of East and West (Kuus 2004).

Turkey, which applied for full EEC membership in 1987, was not so lucky. Even though the EU Commission endorsed the country' eligibility for membership in 1989, it decided to defer the assessment of Turkey's application (EurActiv.com 2006). In 1997 Turkey's eligibility for accession was confirmed again (Europa 2005), but at the Luxembourg summit EU leaders still declined to grant candidate status (EurActiv.com 2006). Turkey's poor record in the implementation of human rights, the military's independence from civilian control, the government's handling of the Cyprus issue, economic problems such as inflation and an inefficient agriculture sector, as well as socio-economic problems such as illiteracy, regional discrepancies in GNP and economic development, were reasons to block negotiations. However, while Turkey, a country with close economic ties to the EU, was left waiting on Europe's doorstep, the door was opened for CEECs, many of which did not meet all accession criteria and presented an economy worse off than Turkey's. Latvia, Lithuania, the Slovak Republic, and in particular Bulgaria and Rumania, in March1998 did not start negotiations together with the Czech Republic, Estonia, Hungary, Poland and Slovenia. Yet the Helsinki European Council in December 1999 agreed to open negotiations with the remaining candidates, even though they only met the political criteria. When it came to Eastern Europe, difficulties in meeting accession criteria were ignored, while Turkey had to wait its turn. Some countries on the European continent appear 'more European' than others in the eyes of the EU. A key difference appears to be the extent to which applicant countries are considered to be sharing cultural proximity with 'old' EU members (Sjursen n/d, 11-12; see also Sjursen 2001). In 
the past, politicians across Europe have expressed concern over Turkish EU membership citing cultural and religious differences (Müftüler-Bac and McLaren 2003, 22). Thus Turkey does not seem to have a place in what appears to be a cultural concept of European identity. Since Turkey was denied membership, relations between the EU and Turkey have improved. Since the Helsinki European Council in December 1999 Turkey is no longer member of an Accession Partnership but an official candidate. Relations improved once Greece, Germany, Britain and the US put their weight behind its application (Müftüler-Bac and McLaren 2003). Still, this does not mean that the concept of 'Turkey as 'other' to Europe no longer crops up. Some observers saw the French and Dutch public's rejection of the European constitution in 2005 at least to some extent motivated by misgivings over Turkey's accession to the EU (Browne 2005, 32), which suggests that citizens too at times operate with a cultural concept of European identity. Responding to public concerns, the EU Commission has launched a civil society dialogue in order to facilitate a dialogue between the people of EU member states and those of candidate countries, such as Turkey. The project involves private and public institutions, such as education and the media, and has a special focus on Turkey 'to ensure that negotiation issues and procedures are understood by the public' (Enlargement Newsletter 2005). Turkey essentially remains the 'other' on the continent while Eastern and Middle European countries were welcomed into the arms of the European family. Thus European identity remains complex. It negotiates both civic and cultural elements. The former appear more clearly articulated than the latter. Democratic institutions, the rule of law and adherence to human rights, for instance, are practices which can be clearly observed. The 'unofficial' criteria of European 'kinship', European 'family' and culture are somewhat fuzzy and difficult to pin down. As the case of Turkey shows, this does not mean, however, that the idea of European cultural identity does not impact on the process of enlargement. Despite being ill-defined, the cultural concept of European identity appears to underpin political processes and influence citizens' approach to European integration. By looking at media discourse this study explores whether one of our main sources of information about the EU teaches us that being a European means sharing cultural traditions, or civic values.

Previous work by Diez Medrano (2003) suggests that the dominant themes in the evaluation of European integration in editorials and opinion pieces across Europe construct a civic concept of European identity (Medrano 2003, 110-114). Newspapers discuss the economic advantage of the single market, the need for European states to unite in order to be economically and militarily competitive. They criticise the functioning of the European institutions and the Common Agricultural Policy (Ibid). Cultural concepts of Europe, such as a common history (the lessons of World War II) and a common destiny (the prospect of a peaceful Europe through European integration) feature as well, but are less prominent 
(Ibid.). The present study picks up on Medrano's findings but takes a more narrowly focused approach. Instead of exploring how often civic and cultural themes occur in general, it explores the context-dependency of identity discourse. Specifically, it asks how concepts of civic and cultural identity are used as discursive tools in the representation of Turkey and CEECs and whether similar to political discourse, news discourse makes a concept of European culture an 'unofficial' accession criterion for EU membership, which Turkey cannot meet.

\section{German and British Approaches to European Integration}

Just like the concept of European identity may not be homogenous within itself, its construction may vary, depending on the cultural and political context which produces it. Country specific approaches to European integration in general may impact on the ways in which European identity is 'imagined'. In order to trace such differences, this study compares press coverage in two 'old' member states: Germany and Britain. Germany today clearly pursues national interests in its approach to European integration, as demonstrated by its push to protect German labour markets in the wake of Eastern enlargement. However, despite recent attempts to actively shape European integration with national interests in mind, commitment to European integration is still integral to German post-war identity (Sperling 1994). Even though Germany pushed for a restriction of immigration from new Eastern members, it has been a key supporter of Eastern enlargement per se. While the economic benefits were not clear for all EU members, Germany could expect to benefit from this process. Among the members of 'old Europe' Germany was the main trading partner of Central and Eastern Europe (Keuschnigg et al. 1999; Staffelt 2001). Under Chancellor Gerhard Schröder's leadership (1998-2005), Germany also put its weight behind Turkey's accession to the EU. Turkish membership was considered crucial in solving social and political problems at home, most notably the integration of Turkish citizens into German society (Müftüler-Bac and McLaren 2003, 24). In contrast to the SPD and the Greens, the Christian Democrats (CDU and CSU) for some time have opposed Turkey's EU membership. Since the 2005 federal election, Germany is governed by a coalition of SPD and Christian Democrats. To date there seems to be no decisive shift in the Christian Democrats' position on Turkey's EU membership (Birnbaum and Meier 2006), yet Chancellor Merkel (CDU) has committed herself to support EU negotiations with Turkey (n/a, Merkel und Erdogan Hand in Hand 2005). Thus on political level, there is commitment to the process of enlargement. In the case of Eastern Europe, this commitment seems to be largely motivated by economic reasoning. Yet given the centrality of European integration for German post-war identity, it is likely that German commitment to Eastern enlargement is at least to some extent also motivated by a concept of shared European history and German cultural identity. In the case of Turkey, Germany's position on the country's accession to the EU appears to be based on national socio-political 
interest. The German political elite are not always in tune with public opinion. Opinion polls suggest that the German public are doubtful about the benefits of enlargement. Concerns over the potential consequences of Eastern enlargement on the German labour market, for example, have contributed to a downturn in public support for European integration (Busch and Knelangen 2004, 87). Yet despite this disjuncture between public opinion and opinions held by the political elite, the majority of German public opinion today still do not question Germany's place in Europe per se. Despite a shift in the public mood, a relatively high level of support has been maintained (Busch and Knelangen 2004, 83). European integration remains central to German identity.

While Germany has made European integration an integral part of its post-war identity, Britain repeatedly has expressed concerns over its loss of national sovereignty to Brussels. Even though Eurosceptic parties fail to win large shares of votes at general elections, public opinion polls consistently show a Eurosceptic public (Spiering 2004, 135). Both the Labour and the Tory party in the past have favoured a European political order that does not go much beyond intergovernmentalism. This approach to European integration is defended by the political elite, but also in news and public discourse with the argument that European integration essentially presents an unwelcome threat to national sovereignty (Medrano 2003, 104-105). Britain's cautious approach to European integration is often defended as a measure to protect national identity (Risse et al. 1999). Britain's role in the Commonwealth and the tradition of a 'special relationship' with the United States underpin the concept of a British identity in which Europe does not take centre stage. Britain's post war international position, but also its adversarial 'winner takes all' power system that does not require the pooling of sovereignty, have also been cited as some of the reasons creating a sense of Britain as being different from Europe (Spiering 2004, 137-138). Notably, in its support for Turkey's EU accession the British Labour government has teamed up with the United States. NATO member Turkey's inclusion into the enlargement process may well have been supported in order to ease NATO and EU negotiations over Europe's Common Security and Defence Policy, and EU access to NATO assets. In the past Turkey has been blocking these negotiations (Müftüler-Bac and McLaren 2003, 27). Similarly, Britain's support for Eastern enlargement was motivated by the British government's attempts to bridge EUUS-UK relationships, hoping that the former communist states would support the USA's relationship with the EU (Baker and Sherrington 2005, 303). British support for Turkish and Eastern European EU membership thus possibly reflects its concerns for the geopolitical and strategic advantages this move might bring, and illustrates how its national interests frame its approach to European integration. Echoing Conservative concerns, British press coverage of EU issues too seems to present EU enlargement through the lens of national interest. British Conservatives and the tabloid press greeted the prospect of Eastern enlargement 
by warning of potential mass immigration from the new member states (Baker and Sherrington 2005, 305). National concerns of finance and foreign policy seem to underpin Britain's approach to European enlargement. Thus, when it comes to the extent to which Europe is perceived to be a threat to national identity, Germany and Britain at times find themselves at almost opposing ends of the spectrum of support for European integration. Country specific cultural and political frames shape their approaches to European integration. The findings of this study suggest that such differences are reflected in press coverage surrounding EU enlargement.

The study compares news coverage published between January 1st 2001 and June 30th 2005. ${ }^{1}$ Two conservative and two left-wing/liberal newspapers from each country have been selected: The Times, The Daily Telegraph, The Guardian and The Independent for the British market, and the Frankfurter Allgemeine Zeitung, Die Welt, the Süddeutsche Zeitung and the Frankfurter Rundschau for the German market. The selection comprises media coverage surrounding several key events in the enlargement process: After in October 1999 the Commission had recommended Member States to open negotiations with Romania, the Slovak Republic, Latvia, Lithuania, Bulgaria and Malta, in October 2002 it recommended to close negotiations with Cyprus, the Czech Republic, Estonia, Hungary, Latvia, Lithuania, Malta, Poland, the Slovak Republic and Slovenia. Negotiations with these countries were concluded in December 2002. At the Copenhagen European Council in the same year Turkey's candidate status was formally reaffirmed. In May 2004 the above CEECs, Cyprus and Malta became EU members and in December of the same year the European Council in Brussels decided to enter into accession negotiations with Turkey as of 3 October 2005 (Auswärtiges Amt 2005; European Commission n.d).

\section{Findings}

Between 2001 and 2005 Turkey and CECCs find themselves in different stages of the accession process. At the 1999 European Council in Helsinki the EU formally laid down Turkey's status as EU candidate (Auswärtiges Amt 2005), yet it was only in 2004 that the European Commission decided to enter accession negotiations with Turkey as of October 2005 (Ibid). Even though accession in 2015 seems possible, Turkey still has not been given an official accession date. In contrast, several Eastern European countries, including the Czech Republic, Hungary, Poland, Slovenia, Slovakia, Latvia, Lithuania and Estonia joined the EU in 2004. Bulgaria and Romania are expected to join in 2007. The different stages of the accession process that Turkey and CEECs find themselves in is reflected in the frequency with which accession criteria and suitability of membership are discussed in relation to these countries. $72.1 \%$ of articles that mention Turkey evaluate the country with reference to either cultural or civic criteria, while for CEECs it is only $46.4 \%$ of all references. 
Looking at the types of criteria used to evaluate EU candidatures, a clear dominance of civic criteria over cultural criteria shows both with reference to Turkey and Eastern European candidates.

Table 1: Civic and cultural criteria mentioned with reference to Turkey and CEECs

\begin{tabular}{|l|l|l|}
\hline & \multicolumn{1}{|c|}{$\begin{array}{c}\text { Articles that refer to Turkey } \\
(\mathrm{n}=165)\end{array}$} & \multicolumn{1}{c|}{$\begin{array}{c}\text { Articles that refer to CEECs } \\
(\mathrm{n}=220)\end{array}$} \\
\hline Civic criteria & $64.2 \%$ & $45.0 \%$ \\
\hline Cultural criteria & $7.9 \%$ & $1.4 \%$ \\
\hline
\end{tabular}

Civic identity here is understood to represent identification with 'a political structure, the state which can be summarised as the set of institutions, rights and rules that preside over the political life of a community' (Bruter 2003, 36). European civic identity is linked to the EU's political and legal system. It refers to the rights and duties of EU citizens (Jiménez et al. 2004, 5). The substance of EU identity here lies in 'its constituent documents, a commitment to the duties and rights of a civic society covering specific aspects of public life, a commitment to the membership of a polity which promotes the direct opposite of the classic ethno-nationalism' (Jiménez et al. 2004, 4). ${ }^{2}$ For the purpose of the analysis, this study has identified any references to criteria outlined by the Copenhagen treaty in the evaluation of specific applicant countries as references that construct a civic concept of European identity. ${ }^{3}$

As the following examples illustrate, the concept of a civic Europe emerges though references to issues of human rights, a functioning market economy and administrative structures:

Bulgaria and Rumania, whose EU accession is scheduled for 2007, are to receive more financial aid as well. The accession partnerships for these two countries identify the reform of the legal system, the administration and economy as priorities. (Frankfurter Allgemeine Zeitung, 27 March 2003, p.4)

Despite US pressure, he insisted Turkey will still have to meet stringent EU human rights criteria before getting the green light to start talks, possibly as soon as next year. (The Guardian, 13 December 2002, p.1)

This civic concept of European identity is further reinforced by references to the political and economic implications of enlargement. Both German and British newspapers associate Turkish and Eastern European membership with consequences for the EU budget, decision making, geopolitical interests and 
immigration. The Times suggests that Turkish EU membership would be a challenge to EU financing and decision making while the Süddeutsche Zeitung points to the geopolitical advantages:

Olli Rehn, the Enlargement Commissioner, who will lead the negotiations for the EU, insisted that two key factors in this absorption capacity would be the budgetary consequences of Turkish membership and the impact its presence would have on the union's ability to take decisions. (The Times, 30 June 2005, p.40)

A fully integrated, democratic and economically stable Turkey would be of influence as far as the Near and Far East. These are the long-term prospects. (Süddeutsche Zeitung, 3 September 2003, p.4)

In the following example, The Times taps into fears over large-scale immigration from new member states, a scenario also conjured by the British Conservative party at the time (Baker and Sherrington, 2005: 305):

Concern about a wave of immigrants from Eastern Europe has prompted countries across the EU to introduce restrictions, with Germany, France, Spain and Italy banning workers from the new EU states for up to seven years. Earlier this week David Blunkett, the Home Secretary, responded to fears over "benefit tourists" by announcing measures aimed at curbing access to benefits, while allowing full access to jobs. (The Times, 27 February 2004, p.21)

It could be argued that if news coverage predominantly creates a scare scenario in which 'old and rich Europe' is 'threatened' by immigration from 'new' and 'poor Europe', then new applicant/member states are kept in a state of 'otherness'. Indeed, it could be argued that such a discourse would draw on the themes of racist discourse, identified by Gerlinde Hardt-Mautner (1995) in her analysis of British news coverage of European summits. Yet while such news coverage might indeed highlight difference between the European and/or national 'self' and new members, it nevertheless presents the $\mathrm{EU}$ as a civic collectivity, unless the dichotomy of 'us' versus 'them' is spiced with references to cultural differences between 'old' and 'new Europe'. References to the Copenhagen criteria and the political and economic consequences of enlargement dominate in the representation of Eastern European countries (45.0\% references) and Turkey (64.2\% of references). Thus a civic concept of European identity emerges and is sustained both in connection with Turkey and Eastern Europe. 
Inthorn, What Does It Mean to Be an EU citizen? ...

Table 2: Consequences of enlargement associated with Turkey and CEECs

\begin{tabular}{|c|l|l|l|l|l|l|l|l|}
\hline & Voting & EU budget & Geopolitical & Immigration & $\begin{array}{c}\text { Foreign } \\
\text { policy }\end{array}$ & $\begin{array}{c}\text { Cultural } \\
\text { clashes/ } \\
\text { meeting of } \\
\text { cultures }\end{array}$ & $\begin{array}{c}\text { End of cold } \\
\text { war } \\
\text { divisions/fut } \\
\text { ure of peace }\end{array}$ \\
\hline Turkey & $\begin{array}{l}\text { British press } \\
(\mathrm{n}=41)\end{array}$ & $7.3 \%$ & $29.3 \%$ & $26.8 \%$ & $9.8 \%$ & $0.0 \%$ & $17.1 \%$ & $0.0 \%$ \\
\cline { 2 - 8 } & $\begin{array}{l}\text { German } \\
\text { press } \\
(\mathrm{n}=124)\end{array}$ & $2.4 \%$ & $12.9 \%$ & $15.3 \%$ & $7.3 \%$ & $2.4 \%$ & $12.9 \%$ & 0.85 \\
\hline $\begin{array}{l}\text { Sample total } \\
(\mathrm{n}=165)\end{array}$ & $3.6 \%$ & $17.0 \%$ & $18.2 \%$ & $7.9 \%$ & $1.8 \%$ & $13.9 \%$ & $0.6 \%$ \\
\hline CEECs & $\begin{array}{l}\text { British press } \\
(\mathrm{n}=54)\end{array}$ & $1.9 \%$ & $31.5 \%$ & $3.7 \%$ & $29.6 \%$ & $1.9 \%$ & $5.6 \%$ & $16.7 \%$ \\
\hline $\begin{array}{l}\text { German } \\
\text { press } \\
(\mathrm{n}=166)\end{array}$ & $1.2 \%$ & $18.1 \%$ & 4.85 & $10.8 \%$ & $3.0 \%$ & $4.2 \%$ & $3.0 \%$ \\
\hline $\begin{array}{l}\text { Sample total } \\
(\mathrm{n}=220)\end{array}$ & $1.4 \%$ & $21.4 \%$ & $4.5 \%$ & $15.5 \%$ & $2.7 \%$ & $4.5 \%$ & $6.4 \%$ \\
\hline
\end{tabular}

This image of a civic Europe can be found in both British and German newspapers. They connect Eastern European countries predominantly with financial consequences for the EU budget and European labour markets. This association of Eastern European countries with consequences for the EU budget is more frequent in British newspapers (31.5 \%) than it is in German newspapers $(18.1 \%)^{4}$. Similarly, immigration is an issue that British newspapers are more likely to associate with Eastern Europe (29.6\%) than German newspapers do (10.8\%) This finding possibly reflects the difference in the extent to which the two countries can expect to benefit from enlargement. Even though Germany expressed concerns over competition from cheap labour in the East and over economic migrants, due to its established economic links with the East, at the same time Eastern enlargement holds clear benefits for the country. In contrast, Britain is a country that sees its rebate from the EU budget threatened by the prospect of comparatively poor countries with large agricultural industries joining the EU. Thus frequent references to matters of immigration and finance indicate how the British newspapers in this sample work within their specific cultural and political context. Thus both German and British newspapers in their references to Eastern Europe predominantly focus on matters of finance and political regulations. Consequently, the image of Europe they construct with reference to CEECs is largely civic in nature.

While CEECs figure as a matter of EU finance and immigration regulations, Turkish membership is most frequently evaluated in terms of geopolitical consequences. As the following examples illustrate, Turkish membership is placed within the context of global politics where the West seeks to stabilise the largely Muslim region to its East. Turkey's potential role as a 'bridge' to the East, or as an ally and 'last outpost' before the region, is considered: 
Yesterday M. Chirac resisted last-minute pressure from Tony Blair and the Italian Prime Minister, Silvio Berlusconi, to make another gesture towards Turkey. ... Mr Berlusconi conceded yesterday that there had been "strong pressure from Turkey, which many didn't like". Others put the blame more squarely on America. ... Pascal Lamy, a French EU commissioner, argued: "It's a classic US diplomacy to want to put Turkey in Europe. The further the boundaries of Europe extend, the better US interests are served." (The Independent, 14 December 2002, p.10)

Turkey's accession to the EU would destroy the European house as we know it. Geopolitical dreams and historical and philosophical fantasies of a "bridge into the Islamic world" are the substitutes on offer. (Frankfurter Allgemeine Zeitung, 7 October 2004, p.1)

References to the geopolitical consequences of Turkish membership are more frequent in British newspapers (26.8\%) than they are in the German press $(15.3 \%)^{7}$. This difference again reflects the cultural and political frames within which German and British newspapers operate. As argued above, British support for Turkish membership is likely to be motivated by the country's geopolitical policy, which it pursues together with the United States.

After its geopolitical role, the financial consequences of Turkish membership figure prominently as a consequence of enlargement. Again such references are more likely to appear in the British press than the German press, reflecting British concerns over its contribution to the budget. With frequent references to such 'civic matters' of enlargement in both the British and German press, it seems as if both the discourse on Turkish membership and the discourse on Central and Eastern European membership constructs a civic concept of European identity.

Yet we can see this image of a civic Union that plays by 'civic rules' challenged when we compare the extent to which Turkey and CEECs are associated with cultural consequences of enlargement. In contrast to civic identity, cultural identity here is understood to represent a citizen's sense of belonging to a particular group of shared cultural and social practices, ethics, or even ethnicity (Bruter 2003, 36). Being a European by this definition means belonging to a common European civilisation, to a society with many languages and cultures. The concept is linked to the idea of common ancestry, history and destiny of Europeans (Jiménez et al. $2004,5)$ and the cultural signifiers of European identity, that citizen refer to include 'peace, harmony, the fading of historical divisions and co-operation between similar peoples and cultures' (Bruter 2003, 36). ${ }^{8}$ For the purpose of its analysis, the study identified the following as references that sustain a cultural concept of European identity: 
1) Reference to, or suggestions of shared cultural proximity or differences between applicant countries and 'old' European member-states: These can include allusions to philosophical foundations, such as the Enlightenment, religious traditions, or any other cultural heritage, such as literature or music.

2) References to a common past and future destiny: These include references to the process of enlargement as ending cold war divisions, and escaping a past of wars fought by Europeans against Europeans.

In both British and German newspapers issues of cultural similarity or difference are more likely to be discussed with reference to Turkey than they are with reference to Eastern Europe9. Thus Turkey is represented as a country where matters of cultural identity need to be considered. Not all articles make it clear what is at stake. The Times speaks of the necessity to ward off a clash of civilisations, others, like the Frankfurter Allgemeine Zeitung, hint at negative consequences for the cultural make-up of existing member states:

EU governments have promised to decide its future in Europe at a summit in December. Britain and Germany insist that admitting Turkey, a country of 70 million Muslims, is vital to ward off the so-called "clash of civilisations". (The Times, 4 May 2004, p.13)

Accepting Turkey into the EU lacks democratic legitimacy if, before making any promises to the Turkish government, [the] Red-Green [coalition government] does not openly discuss their financial, political and cultural consequences and ties an electoral decision to them. (Frankfurter Allgemeine Zeitung, 16 December 2002, p.8)

Other articles go further and explicitly make a particular culture an accession criteria which applicants should fulfill:

Yet instead of preparing Europe for a 'spiritual reunification', government leaders of the fifteen [members] have smoothed the pathway for Turkey to enter into this fragile and uncertain Union. It reveals how unseriously they take occidental culture, which is the only possible basis for a European Union. (Frankfurter Allgemeine Zeitung, 16 December 2002, p.1)

So why should not Turkey's credentials eventually be accepted? I fear there is only one reason - and it is the one stated by Giscard D'Estaing: Turkey is not a European country. In taking that fact seriously, we don't necessarily fall into cultural bigotry and racism. Turkey has a traditional pull towards both Central Asia and the Middle East. With Turkey in the EU our borders will include Iran and Iraq. (Daily Telegraph, 18 December 2002, p.28) 
Thus even though news coverage both in Germany and Britain predominantly constructs a civic concept of Europe, Turkey is introduced as a country where cultural difference matters more than it does for other countries. Cultural identity becomes an unofficial accession criterion and the cultural concept of Europe becomes a discursive tool used in arguments against Turkish membership. In contrast, CEECs are rarely connected with the cultural consequences of enlargement. Exceptions are references to the memory of the Second World War, or a European future of peace and harmony. These appear more often in relation to Eastern Europe than in relation to Turkey. Yet as the following example shows, associations between the memory of war and Eastern Europe do not support discursively established divisions between Europe and new applicants. On the contrary, they are elements of a European cultural identity of which Eastern Europe is a 'natural' member. The East has finally 'come home' to Europe:

It would be a mistake to ascribe their [the ten candidates for EU enlargement] push into the EU to the attraction of the European model. The real reasons are more complex. The most important one being: historically being part of 'Europe' which now happens to be organizing itself in the form of the EU. (Frankfurter Allgemeine Zeitung, 4 January 2002, p.1)

This is not to say that the majority of articles openly argue for an exclusion of Turkey on reasons of cultural difference. References to the cultural consequences of Turkish accession are frequent, but not as dominant as references to the EU budget and geopolitical consequences. Yet the frequency with which certain criteria, or consequences are referred to, does not reveal the whole extent to which representations of Turkey sustain a cultural concept of European identity. By looking at the linguistic choices made at sentence level, we can see how the concept of Turkey as the cultural 'other' is sustained even in a context that on surface level supports a civic concept of European identity. As the following example illustrates, in articles that evaluate Turkish membership against civic criteria Turkey is frequently referred to as a Muslim state, or its Islamic heritage is mentioned:

But the prospect of starting negotiations with a large, impoverished and mainly Muslim country of 70 million people has caused acute anxiety in several EU capitals. (The Independent, 17 December 2004, p.20)

In such references Turkey is introduced not just as a challenge for the EU budget and voting procedures. As the term 'mainly Muslim' is added, Turkey becomes defined as a cultural problem at the same time. In $30.2 \%$ of articles that mention civic criteria in relation to Turkey, the terms 'Islam' or 'Muslim' are included as well, usually in references to Turkey's population, culture or political institutions. 
The idea of European cultural values thus 'sneaks' into what otherwise is represented as a civic and culturally inclusive concept of European identity.

Thus the representations of CEECs and Turkey both sustain a civic concept of Europe. However, in the representation of Turkey a cultural concept of Europe is negotiated at the same time. The discourse of European identity is complex. While overall we can see a civic and culturally inclusive concept, when it comes to Turkey cultural criteria appear as well. Turkey is represented as a 'problem' and cultural challenge for the EU. While Central and Eastern Europe appears as 'natural' member of the European family, Turkey remains the 'other' and is excluded from the community of Europeans on the basis of its cultural identity.

\section{Conclusion}

The analysis of news coverage from two 'old' members of the EU suggests that readers predominantly get to see Europe as a civic collectivity. Matters of financing, immigration and geopolitical policies feature prominently. The extent to which newspapers refer to such matters appears dependant on their countryspecific contexts. The British press makes these issues more central to the process of enlargement than the German press, reflecting the British approach to European integration in general. Whereas for Germany benefits of enlargement are likely, Britain faces challenges to its rebate and supports geopolitical strategies favoured also by the US. Germany, traditionally considered as a historically motivated' champion of Eastern enlargement only rarely summons the memory of the Second World War, or the idea of a European future of peace. By 2001 the country seems to be more concerned with the costs of enlargement than with its historical significance. By focusing mainly on issues of finance, immigration and geopolitics, news discourse in both countries overall constructs a civic concept of European identity. Yet the concept of cultural identity too has a clear presence. The findings of this study show how the discursive construction of cultural and civic identity is context-dependant. While the representation of CEECs predominantly draws on civic elements of identity, the representation of Turkey frequently makes references to the cultural consequences of Turkish membership. The question of whether Turkey's 'traditional tendencies towards Central Asia' and its Islam heritage lead to inevitable clashes with European Christianity, or would help to ward off a 'clash of civilisations' in particular features in the evaluation of Turkey's suitability as an EU member. Indeed Islam becomes the seemingly natural marker by which Turkish identity is to be understood. References to cultural difference and cultural consequences of Turkish accession to the EU construct a cultural concept of European identity. Unlike in the representation of CEECs, in news discourse surrounding Turkey's long journey towards EU membership, the cultural concept of European identity becomes a discursive tool to mark the country as the eternal 'other' to Europe. The representation of Eastern Europe 
does not feature similar qualms over cultural identity. On the contrary, it is identified as a 'natural' member of the European family. Thus readers in Britain and Germany get to see a complex image of European identity, which negotiates potentially conflicting civic and cultural elements. What is more, they also get to see that the concept of European culture is to be mobilised in a specific context. When it comes to Turkish EU membership, the European 'self is to be 'guarded' against the Muslim 'other'.

\section{Notes}

${ }^{1}$ The sample comprises all main articles on the Lexis-Nexis database containing the keywords 'EU' and 'enlargement' together with either 'Eastern Europe' or 'Turkey'. The narrow range of keywords means that this sample does not allow for any claims about the totality of news coverage on enlargement between 2001 and 2005. Yet it suffices to give a first indication of how new EU members and future applicant countries are measured against civic and cultural criteria of European identity.

${ }^{2}$ Of course, when it comes to making decisions over who 'belongs' to Europe, not every citizen makes their decision dependant on the judgement of whether Europe is a cultural collectivity or not. As the example of German public opinion on EU enlargement suggests, citizens' attitudes towards aspects of European integration are often guided by the perceived costs and benefits these aspects have to offer (Wood 2002, 25). Therefore some authors have chosen to define an additional, socalled 'instrumental' element of collective identities, which reflect a cost/benefit approach to Europe (See Jiménez et al. 2004). Common social security, a welfare system, common borders, a common economy and an army, are key components of this identity (Ibid). The distinction between civic and instrumental identities works better at theoretical level than in practice. Benefits enjoyed by EU citizens, such as the right to free movement or a European defence force, are ultimately linked to the EU's constituent documents and citizens' rights. They are therefore both instrumentalist and civic in nature. The present study does not wish to discard the general usefulness of distinguishing between instrumental and civic elements of identity. Yet similar to the approach taken by Bruter (2003), for the purpose of the argument that is to be made here, the broader distinction between civic and cultural identity suffices. The central aim of this study is to explore how notions of cultural identity or 'kinship', and concepts of civic identity are negotiated in references to CEECs and Turkey. The main distinction thus lies between these two categories and not within the category of civic identity. Therefore this study defines such arguably 'instrumentalist' components such as access to a welfare system and common borders, as elements of civic identity.

3 These criteria include: stability of institutions, democracy, the rule of law, human rights and respect for and protection of minorities. They also include references to 
an applicant countries' economy and its ability to take on the obligations of membership including the aims of political, economic and monetary union, and administrative structures. In addition, references to the implications a country's EU membership has on the EU budget, its common market (due to the right to free movement and borderlessness), EU decision making and distribution of votes, EU foreign policy and geopolitical interests, have been identified as references that construct a civic concept of European identity.

${ }^{4}$ Sig $=0.037$

${ }^{5} \mathrm{Sig}=0.001$

${ }^{6}$ Own quotation marks.

${ }^{7} \mathrm{Sig}=0.098$

8 Some authors distinguish between what Jiménez et al. (2004) term 'affectivesymbolic' elements of identity, such as pride in the symbols of one's collectivity, and cultural identity. Even though these two categories allow the distinction between emotive and less emotive components of identity, for the purpose of this study it suffices to group references to European symbols under the broader heading of cultural identity.

9 Sample total: Sig $=0.000$; German sample: $\operatorname{Sig}=0.007$; British sample: the difference in frequencies is similar to the German sample, yet the cell count is too small to test the statistical significance for this difference.

\section{References}

Anderson, P. (2004) 'A Flag Of Convenience? Discourse and Motivations of the London-Based Eurosceptic Press', European Studies, 20:151-170.

Anderson, P. and A. Weymouth (1999) Insulting the Public? The British Press and the European Union, London: Longman.

Armbruster, H., C. Rollo, and U. Meinhof (2003) 'Imagining Europe: Everyday Narratives in European Border Communities', Journal of Ethnic and Migration Studies, 29(5): 885-899.

Auswärtiges Amt (2005) 'Relations between Turkey and Germany', available at http://www.auswaertiges-

amt.de/www/en/laenderinfos/laender/laender_ausgabe_html?land_id=17 6 (accessed 30 July 2005).

Baker, D. and P. Sherrington, (2005) 'Britain and Europe: The Dog That Didn't Bark', Parliamentary Affairs, 58(2): 303-317.

Birnbaum R. and A. Meier (2006) 'Kein Bonus für EU-Beitritt Union sieht Schlüsselrolle Ankaras - aber mehr nicht', available at http://www.tagesspiegel.de/politik/archiv/11.02.2006/2346517.asp (accessed 12.06.2006).

Browne, A.(2005) 'Eleventh-Hour Call for the EU to Halt Its Talks with Turkey', The Times, June 28, p.32. 
Bruter, M. (2003) 'On What Citizens Mean by Feeling 'European': Perceptions of News, Symbols and Borderless-Ness' Journal of Ethnic and Migration Studies, 30(1): 21-39.

Busch, K.and W. Knelangen (2004) 'German Euroscepticism', European Studies, 20: 83-98.

Carey, S. and J. Burton, (2004) 'Research Note: The Influence of the Press in Shaping Public Opinion towards the European Union in Britain' Political Studies, 52: 623-640.

Delgado-Moreira, J. (1997) 'Cultural Citizenship and the Creation of European Identity', available at http://www.sociology.org/content/vol002.003/delgado.html (accessed 30 June 2005).

Enlargement Newsletter (2005), available at http://europa.eu.int/comm/enlargement/docs/newsletter/latest_weekly.h tm\#wha (accessed 25 August 2005)

EurActiv.Com (2004) 'European Parliament Elections 2004: Results', available at http://www.euractiv.com/Article?tcmuri=tcm:29-11748216\&type $=$ LinksDossier (accessed 25 August 2005).

EurActiv.Com (2006) 'EU-Turkey relations', available at http://www.euractiv.com/en//eu-turkey-relations/article-129678 (accessed 28 September 2006).

Europa (2005) 'Memo/05/227', available at http://europa.eu/ $\mathrm{rapid} /$ pressReleasesAction.do? reference $=\mathrm{MEMO} / 05 / 22$ $7 \&$ format $=$ HTML\&aged $=0$ \&language $=E N \&$ guiLanguage $=$ en $($ accessed 28 September 2006).

European Commission Directorate-General "Enlargement" (n/d) 'EU

Enlargement - A Historic Opportunity', available at http:// europa.eu.int/comm/enlargement/intro/criteria.htm (accessed 2 July 2005).

European Commission (n/d) 'Enlargement' available at http://europa.eu.int/comm/enlargement/negotiations/index.htm (accessed 30 July 2005).

Hardt-Mautner, G. (1995) 'How Does One Become a Good European?': The British Press and European Integration', Discourse and Society 6(2):177-205. Hargreaves, I., and J. Thomas (2002) New News, Old News, London: Independent Television Commission.

Infoeuropa (n/d) 'Enlargement Process', available at http://www.infoeuropa.ro/jsp/page.jsp?cid=7\&lid=2 (accessed 28 September 2006). 
Inthorn, What Does It Mean to Be an EU citizen? ...

Jileva, E. (2004) 'Do Norms Matter? The Principle of Solidarity and the EU's Eastern Enlargement', Journal of International Relations and Development, 7: 323.

Jiménez, A., G. Ruiz, J.Juroslaw, A. Kosic, P. Kiss, and M. Kandulla (2004) 'Europe and National Identities in Europe's Old and New Member States: Ethnic, Civic. Instrumental and Symbolic Components' European Integration Online Papers (EIoP), 8(11): 1-23.

Keuschnigg, C., M. Keuschnigg, and W. Kohler (1999) 'Eastern Enlargement to the EU: Economic Costs and Benefits for the Present Member States? Germany' Final Report on Study XIX/B1/9801, Saarbrücken, Linz: University of Saarland, University of Linz.

Kuus, M. (2004) 'Europe's Eastern Expansion and the Reinscription of Otherness in East-Central Europe' Progress in Human Geography 28(4): 472-489.

Mayer, F. and J. Palmowski (2004) 'European Identities and the EU: The Ties that Bind the Peoples of Europe', JCMS, 42(3): 573-598.

Medrano, D. (2003) Framing Europe. Attitudes to European Integration in Germany, Spain, and the United Kingdom, Princeton: Princeton University Press.

(n/a) (2005) 'Merkel und Erdogan Hand in Hand', available at http://www.stern.de/politik/ausland/550441.html?nv=ct_mt (accessed 12 June 2006).

Müftüler-Bac, M. and L. McLaren (2003) 'Enlargement Preferences and PolicyMaking in the European Union: Impacts on Turkey', European Integration, 25: 17-30.

Risse, T., D. Engelmann-Martin, H. Knopf, and K. Roscher (1999) 'To Euro or Not to Euro? The EMU and Identity Politics in the European Union' European Journal of International Relations, 5(2): 147-187.

Sjursen, H. (2001) 'Why Expand? The Question of Justification in the EU's Enlargement Policy', ARENA Working Papers WP 01/6., available at http://www.arena.uio.no/publications/wp01_6.htm (accessed 12 June 2006).

(n.d) 'Towards as Post-National Foreign and Security Policy?', ARENA

Working Papers, WP 04/12: 1-28, available at

http://www.arena.uio.no/publications/working-

papers2004/papers/wp04_12.pdf (accessed 12 June 2006).

Sjursen, H. and K Smith (2001) 'Justifying EU Foreign Policy: The Logics

Underpinning EU Enlargement', ARENA Working Papers WP 01/1, available at http://www.arena.uio.no/publications/wp01_1.htm (accessed 12 June 2006).

Sperling, J.(1994) 'German Foreign Policy after Unification: The End of Cheque Book Diplomacy?' West European Politics, 17(1): 73-97.

Spiering, M. (2004) 'British Euroscpeticism', European Studies, 20: 99-126. 
Staffelt, D. (2001) 'Erwartungen für Deutschland aus gesamtwirtschaftlicher Sicht' Friedrich Ebert Stiftung Digitale Bibliothek, available at http://library.fes.de/fulltext/fo-wirtschaft/00955008.htm (accessed24 August 2005).

Van Westering, J. (2000) 'Conditionality and EU Membership: The Cases of Turkey and Cyprus', European Foreign Affairs Review, 5: 95-118.

Wood, S. (2002) 'Germany and the Eastern Enlargement of the EU: Political Elites, Public Opinion and Democratic Processes', European Integration, 24(1): 23-38. 